ARTICLE

Received 22 Mar 2014 | Accepted 11 Jun 2014 | Published 10 Jul 2014

DOI: $10.1038 /$ ncomms5375

\title{
Southern Annular Mode-like changes in southwestern Patagonia at centennial timescales over the last three millennia
}

Patricio I. Moreno ${ }^{1,2,3, \star}$, I. Vilanova ${ }^{4, \star}$, R. Villa-Martínez ${ }^{2,3,5}$, R.D. Garreaud ${ }^{3,6}$, M. Rojas ${ }^{3,6}$ \& R. De Pol-Holz ${ }^{3,7}$

Late twentieth-century instrumental records reveal a persistent southward shift of the Southern Westerly Winds during austral summer and autumn associated with a positive trend of the Southern Annular Mode (SAM) and contemporaneous with glacial recession, steady increases in atmospheric temperatures and $\mathrm{CO}_{2}$ concentrations at a global scale. However, despite the clear importance of the SAM in the modern/future climate, very little is known regarding its behaviour during pre-Industrial times. Here we present a stratigraphic record from Lago Cipreses $\left(51^{\circ} \mathrm{S}\right)$, southwestern Patagonia, that reveals recurrent $\sim 200$-year long dry/warm phases over the last three millennia, which we interpret as positive SAM-like states. These correspond in timing with the Industrial revolution, the Mediaeval Climate Anomaly, the Roman and Late Bronze Age Warm Periods and alternate with cold/wet multicentennial phases in European palaeoclimate records. We conclude that SAM-like changes at centennial timescales in southwestern Patagonia represent in-phase interhemispheric coupling of palaeoclimate over the last 3,000 years through atmospheric teleconnections.

\footnotetext{
${ }^{1}$ Department of Ecological Sciences, Universidad de Chile, Las Palmeras 3425, Casilla 653, Santiago, Chile. ${ }^{2}$ Institute of Ecology and Biodiversity, Universidad de Chile, Las Palmeras 3425, Casilla 653, Santiago, Chile. ${ }^{3}$ Center for Climate Research and Resilience, Universidad de Chile, Blanco Encalada 2002 , Santiago 8370449, Chile. ${ }^{4}$ CONICET-Museo Argentino de Ciencias Naturales Bernardino Rivadavia, Sección Palinología del Cuaternario, Av. Angel Gallardo 470, Buenos Aires C1405DJR, Argentina. ${ }^{5}$ GAIA-Antártica, Universidad de Magallanes, Avenida Bulnes 01890, Punta Arenas 621-0427, Chile. ${ }^{6}$ Department of Geophysics, Universidad de Chile, Blanco Encalada 2002, Santiago 8370449, Chile. ${ }^{7}$ Department of Oceanography, Universidad de Concepción, Barrio Universitario s/n, Casilla 160-C, Concepción, Chile. ${ }^{\star}$ These authors contributed equally to this work. Correspondence and requests for materials should be addressed to P.I.M. (email: pimoreno@uchile.cl).
} 
istorical and palaeoclimate records from the North Atlantic and Europe were the first to reveal centennialscale swings in temperature and precipitation over the last millennia, the most recent of which are referred to as the Medieval Warm Period (also named the Medieval Climate Anomaly, MCA, $0.8-1.1 \mathrm{ka}\left(\mathrm{ka}=10^{3}\right.$ cal yr BP (calendar years before present, present $=\mathrm{AD} 1950)$ ), $\mathrm{AD}$ 1350-750) and the Little Ice Age (LIA, $0.1-0.6 \mathrm{ka}, \mathrm{AD} 1850-1350)^{1}$. These climatic anomalies occurred during profound land-use changes and before large increases in atmospheric greenhouse gas concentrations associated with the Industrial Revolution. Therefore, studying the timing, structure, magnitude, direction and geographic variability of centennial-scale events such as the MCA and the LIA may help us to understand the causes and consequences of climate change under natural boundary conditions not dissimilar from the modern. More recent studies carried out in the tropics and subtropics have suggested that centennial-scale changes in precipitation regimes have occurred over the last two millennia, with alternations between modes of variability akin to the modern functioning of the El NiñoSouthern Oscillation ${ }^{2,3}$. Heterogeneities in timing and direction of changes are evident among these low-latitude records, possibly reflecting antiphased response patterns or varying degrees of stationarity of the climate teleconnections among the studied regions.

Little is known, however, about centennial-scale changes in temperature and precipitation regimes in the southern extra tropics during the most recent millennia, a vast sector characterized by a strong zonal atmospheric circulation pattern imparted by the Southern Westerly Winds (SWW) ${ }^{4}$. Late twentieth century instrumental and reanalysis data indicate an acceleration and southward shift of the SWW during austral summer and autumn ${ }^{5}$, contemporaneous with a global warming trend, increasing atmospheric $\mathrm{CO}_{2}$ concentrations and persistently positive phases of the $\mathrm{SAM}^{6}$ (also known as the Antarctic Oscillation), the main mode of atmospheric variability in the mid- and high-latitudes of the Southern Hemisphere ( $\mathrm{SH}$; Supplementary Discussion). This atmospheric trend has been attributed to human-induced changes in atmospheric chemistry during the twentieth century ${ }^{7}$. The shortness of climate records from the $\mathrm{SH}$, however, impedes appreciation of whether this phenomenon is superimposed on natural, low-frequency climate variability. Modelling and empirical studies have proposed that variations in SWW-driven upwelling over the Southern Ocean (SO) have modulated ocean-atmospheric $\mathrm{CO}_{2}$ fluxes through degassing of the deep ocean during key climatic transitions, that is, glacial terminations 8,9 , millennial-scale shifts during the last glaciation and the Holocene ${ }^{10,11}$. Hence, it is of uttermost importance to determine whether the SWW-SO-CO 2 -coupled system holds for the most recent centuries and millennia, as it may constitute a source of positive climate feedback that needs to be fed into numerical simulations of future climate change under various global warming scenarios.

Patagonia is a key region to examine variations of the SWW in the middle latitudes of the SH. The amount of precipitation along its western sector exhibits a positive and significant correlation with low-level zonal wind intensity over a broad swath of the southern mid-latitudes ${ }^{12}$ (Fig. 1). Climate analyses have also detected a strong positive correlation between SAM and temperature throughout Patagonia $\left(40^{\circ}-54^{\circ} \mathrm{S}\right)$ and a negative correlation with zonal wind intensity and precipitation during summer in Patagonian sectors north of $\sim 50^{\circ} \mathrm{S}$ (Supplementary Discussion and Supplementary Figs 1-3). The sign of these SAMrelated climate anomalies over Patagonia is notably stable between the pre- and post-1979 periods, consistent with the location of the study area well into the southern mid-latitudes,
Correlation 1979-2001<u850,pr

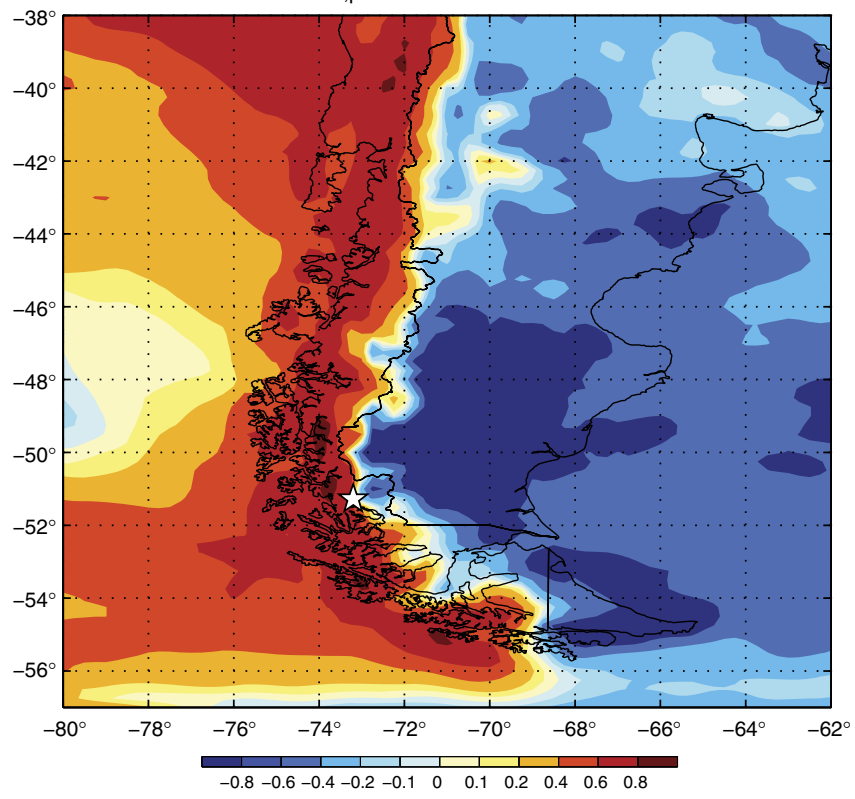

Figure 1 | Map of the study area and correlation fields between local precipitation and zonal wind speed. We correlated the zonal wind at $850 \mathrm{hPa}$ from a regional climate simulation (PRECIS) forced by ERA40 lateral boundary conditions (see details in ref. 4), for the period 1979-2001. The white star indicates the location of Lago Cipreses.

unlike the less stable SAM-related anomalies in subtropical South America $^{13}$ (Supplementary Discussion). Tree-ring studies along sectors adjacent to the western and eastern flanks of the northern and southern Patagonian Andes detected anomalous growth patterns ${ }^{14}$ over the last 600 years, associated with temperature/ precipitation anomalies characteristic of the SAM. Moreover, firescarred tree data along western Patagonia reveal increased fire activity associated with positive departures of the SAM ${ }^{15}$.

Vegetation composition and distribution in southwestern Patagonia are highly dependent on precipitation delivered by atmospheric disturbances embedded in the SWW. The lowland vegetation of southwestern Patagonia $\left(>48^{\circ}\right.$ S) includes Magellanic forest communities, dominated by the evergreen Nothofagus betuloides (Magellanic beech) along with the cold-resistant conifers Pilgerodendron uviferum, Podocarpus nubigena and other hygrophilous trees (Drimys winteri, Tepualia stipularis) that intermingle with Magellanic Moorlands in the wettest sectors $\left(2,000-6,000\right.$ mm year $\left.^{-1}\right)$ adjacent to the Pacific coast ${ }^{16}$. The winter-deciduous Nothofagus pumilio is most abundant in lowland forests located downwind (eastward) in less humid areas $\left(\sim 750 \mathrm{~mm}\right.$ year $\left.^{-1}\right)$, intermingling with Nothofagus Antarctica-dominated woodlands in drier sectors ( $\sim 450 \mathrm{~mm}$ year $^{-1}$ ) adjacent to the forest-steppe ecotone. The shrubs Escallonia serrata, Berberis ilicifolia and Embothrium coccineum occur in the margins of $N$. betuloides- or N. pumiliodominated forests, and the ferns Blechnum penna-marina, Hymenophyllum spp. are abundant under relatively open canopy conditions or tree-fall gaps. Deciduous forests and woodlands transition into the Patagonian steppe east of the Andes in response to a strong rainshadow induced by the abrupt relief. The composition and distribution of this transition is dependent on the amount of precipitation of westerly origin that spills eastward over the cordillera. Meteorological data from Torres del Paine National Park $\left(51^{\circ} \mathrm{S}\right)$, an area located in the forest-steppe ecotone of southwestern Patagonia, exhibit a strong positive correlation between local precipitation and zonal wind 
intensity ${ }^{17}$; the strength of this correlation diminishes and turns negative in stations located towards the Atlantic coast ${ }^{4}$. Hence, hydroclimate inferences based on palaeovegetation, past lake level changes and palaeofire-regime shifts from the western sectors of southern Patagonia constitute a valuable source of information for reconstructing past variations of the SWW and SAM.

Here we present palynological and fire history data from sediment cores collected from Lago Cipreses (LC), a small closedbasin lake located in the Magallanes region of southern Chile $\left(51^{\circ} \mathrm{S}\right)$, to characterize centennial-scale changes in the SWW during the last three millennia akin to the modern functioning of SAM.

\section{Results}

Vegetation and fire history. LC is surrounded by mixed evergreen-deciduous Magellanic forests that have experienced relatively minor disturbance since the arrival of Europeans, owing to the inaccessibility of the area and the natural fire break established by Lago Toro. In contrast, more accessible areas located $20-30 \mathrm{~km}$ north (Torres del Paine National Park) and south (Puerto Natales) have witnessed large-scale disturbance by fire, logging and livestock grazing since local European settlement starting in AD 1870 (ref. 18). We retrieved sediment cores from LC showing undisturbed, continuous pelagic sedimentation since $\sim 15 \mathrm{ka}$ (Supplementary Discussion, Supplementary Figs 4-6). The pollen and charcoal records show dominance of Nothofagus along with the hygrophilous conifers Pilgerodendron uviferum, Podocarpus nubigena and traces of Drimys winteri since $3 \mathrm{ka}$ (Fig. 2, Supplementary Fig. 7), which we interpret as local dominance of Magellanic forests with varying degrees of openness in response to environmental change. Over this interval, we detect five intervals $(\mathrm{CC} 1(\mathrm{CC}=$ Cipreses cycle): $\mathrm{AD} 1890$-present, CC2: 0.8-1.1, CC3: 1.4-1.55, CC4: 1.8-2.1 and CC5: 2.7-2.9 ka) during which the abundance of Nothofagus declined and reached values between 65 and $85 \%$, accompanied by increases in herbs, ferns and macroscopic charcoal, all indicative of fragmentations/discontinuities in the forest canopy, proliferation of understory shrubs/herbs and enhanced fire activity. The macrophyte Cyperaceae covaries (1-7\%) with the terrestrial herbs suggesting

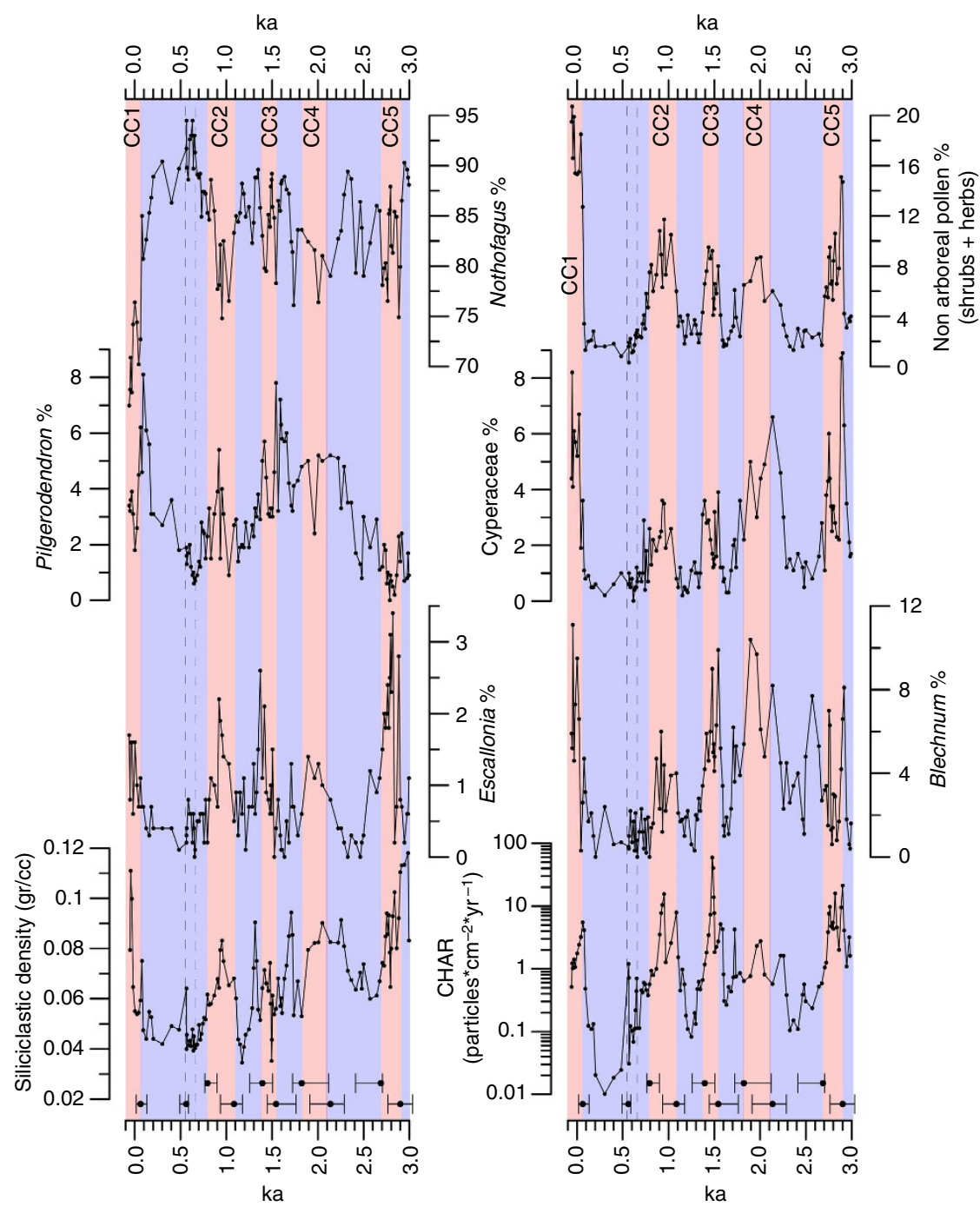

Figure 2 | Summary of the Lago Cipreses record. We emphasize the timing of dry/warm phases (red vertical rectangles) that alternate with cold/humid phases (blue vertical rectangles). The dashed vertical rectangle indicates the timing of the highest abundance of Nothofagus during the most recent hyperhumid anomaly. The numbered labels indicate the dry/warm events recorded in the Lago Cipreses record (CC: Cipreses Cycle), the solid black circles in the bottom of the figures indicate the median probability age for the transitions identified in this record, the error bars define the $95 \%$ confidence interval associated to these transitions according to a Bayesian age model. 
that littoral vegetation was able to expand towards deeper sectors of the lake repeated times in response to lower stands (Fig. 2, Supplementary Fig. 7). We note that Escallonia and the siliciclastic density data display nearly identical fluctuations in phase with the aquatic vegetation changes described above, which we interpret as colonization of Escallonia shrublands on the substrates exposed by lake level lowering, increased runoff and erosion associated with vegetation clearings driven by local fires. Each CC is followed by a rise in arboreal pollen reaching maxima between 85 and 95\%, decrease in aquatic macrophytes and decline in charcoal, suggesting re-establishment of closedcanopy forests, relatively deep lake conditions and muted fire activity. CC3 and CC4 feature the lowest magnitude of NonArboreal Pollen (NAP) rise, followed by CC2, then CC5 and CC1 with the fastest, largest-magnitude increase on record. We note a rapid Nothofagus increase that reached peak abundance between 0.55 and $0.65 \mathrm{ka}$ and declined $\sim 8 \%$ gradually until AD 1890 , contemporaneous with a sustained rise in P. uviferum of similar magnitude. Both hygrophilous trees decline rapidly at $\mathrm{AD} 1890$ concomitant with an abrupt increase in herbs and shrubs, including the appearance of the European weed Rumex acetosella, along with a conspicuous rise in macroscopic charcoal (CC1; Supplementary Discussion, Supplementary Figs 7-10).

Palaeoenvironmental interpretation. Taken together, the pollen, charcoal and sedimentary records from LC suggest the occurrence of $\sim 200$ year-long dry/warm phases alternating with wet/ cold intervals during the last 3,000 years in southwestern Patagonia. Given that precipitation in this sector is derived exclusively from the SWW and that local precipitation and summer temperature are positively/negatively correlated with zonal wind velocity, respectively, we infer secular changes in zonal SWW strength over the study area. The character and direction of these changes suggest large-scale shifts in mid- and high-latitude atmospheric circulation similar to the modern functioning of SAM in Patagonian sectors north of $\sim 50^{\circ} \mathrm{S}$ during austral summer and autumn, with negative centennial-scale anomalies in precipitation regime and positive air temperature anomalies (positive SAM-like) responsible for intensified fire activity, forest fragmentation, erosion and lake-level lowering. In contrast, we ascribe muted fire activity, lake-level rises and establishment of closed-canopy Magellanic forests to positive centennial-scale anomalies in precipitation and negative temperature anomalies (negative SAM-like). The most recent of these dry/warm phases (CC1) has been in effect since AD 1890 and corresponds in timing with the Industrial Revolution, a persistent southward shift of the SWW during austral summer and a persistent trend towards positive SAM revealed by instrumental records since the mid-twentieth century (Fig. 3).

\section{Discussion}

We standardized the LC NAP curve to the mean of the last three millennia to summarize the major trends in the LC record and facilitate comparisons with other studies. Positive anomalies in this parameter are interpreted as warm/dry intervals analogue to positive SAM-like states; negative anomalies correspond to cool humid/hyperhumid intervals and are interpreted as negative SAM-like states (Fig. 3). Comparison with the Nothofagus/ Poaceae Index from Lago Guanaco (LG) ${ }^{19}$, a palecoecological site located $\sim 30 \mathrm{~km}$ downwind from LC in a sector adjacent to the modern forest-steppe ecotone, reveals large-magnitude shifts associated with CC5, the hyperhumid interval between AD 1890$0.65 \mathrm{ka}$ and CC1 (Fig. 3). These shifts reflect major physiognomic changes in the vegetation near LG from a graminoid steppe to a
Nothofagus scrubland at $2.8 \mathrm{ka}$, followed by forest expansion at $\sim 0.8 \mathrm{ka}$ and rapid deforestation at AD 1890 driven by intense European disturbance. The relatively minor or muted changes between approximately 0.8 and $2.8 \mathrm{ka}$ might reflect resilience of Nothofagus scrublands located near the forest-steppe ecotone to natural climate/disturbance variability under intermediate levels of precipitation. In contrast, the continuity of the forest canopy revealed by the LC Nothofagus/Poaceae Index parameter shows high sensitivity to the CCs and intervening humid phases, illustrating the capacity of forest vegetation to recover its original condition following natural climatic/disturbance disruptions at centennial timescales.

Both the LC and LG records compare reasonably well with a recent reconstruction of SAM that spans the last 600 years $^{14}$ based on an extensive network of tree-ring chronologies from Tasmania, New Zealand and sectors of Patagonia located east and west of the Andes, north and south of LC. The hyperhumid phase dated in LC between AD 1890 and $0.65 \mathrm{ka}$ is contemporaneous with strongly negative anomalies in tree-ring inferred SAM (Fig. 3, Supplementary Fig. 9) and the maximum extent of multiple alpine glaciers in Patagonia ${ }^{20}$ and the southern Alps of New Zealand ${ }^{21}$. This was followed by an abrupt onset of warm/ dry conditions and intense fire activity at the onset of CC1 (AD 1890, $\pm 2 \sigma: 1933-1818$ ) contemporaneous with a rising trend in tree-ring-based temperature reconstructions from northern and southern Patagonia ${ }^{22}$, and predate a rapid increase in tree-ringreconstructed SAM at $\mathrm{AD}$ 1950. The tree-ring reconstruction and time-series analysis of weather station data published by Villalba et al. ${ }^{14}$, along with our stratigraphic record from LC and regional climate analysis, indicate that carefully selected sites from sensitive sectors throughout Patagonia are capable of monitoring hemispheric-wide modes of variability such as SAM, despite the complex relief and climatic heterogeneity stressed in a recent study ${ }^{23}$.

We now compare the timing and structure of palaeoclimate changes observed in LC with palaeoclimate records from the SE Pacific and North Atlantic/European regions. Figure 3 shows the alkenone $^{24}$ and $\mathrm{Fe}$ intensity data ${ }^{25}$ from core GeoB3313-1, obtained from the Chilean continental slope $\left(\sim 41^{\circ} \mathrm{S}\right)$ and interpreted as sea surface temperature and amount of precipitation delivered by the SWW in northwestern Patagonia, respectively. We observe an apparent match between the LC NAP and the alkenone record and a variable relationship with the Fe intensity record, which might represent an in-phase, antiphase or out-of-phase precipitation pattern between northwestern and the LC record, depending on the interpretation of the Fe intensity data (Supplementary Discussion). We also compare our results with proxies of ice-rafting ${ }^{26}$, intensity of Atlantic Meridional Overturning Circulation (AMOC) ${ }^{27}$ preserved in North Atlantic sediment cores and air temperature change recorded in a speleothem from Crag Cave in SW Ireland ${ }^{28}$ since $3 \mathrm{ka}$. We note partial convergence among these North Atlantic records and the European palaeoclimate chronology, suggesting regional heterogeneities at centennial timescales or differences in chronologic precision/accuracy/sensitivity of the selected records. Acknowledging these sources of error, we observe that CC1, CC2, CC4 and CC5 were quasi-contemporaneous with the twentieth century industrial warming, the Mediaeval (=MCA), Roman and Late Bronze Age Warm Periods, respectively (Fig. 3, Supplementary Discussion). The intervening hyperhumid (AD $1890-0.8 \mathrm{ka})$ and humid $(1.1-1.8,2.1-2.7 \mathrm{ka})$ phases overlap in timing with the LIA, the Dark Ages (DACP) and Iron Age Cold Periods, respectively. The $1.1-1.8 \mathrm{ka}$ cold/wet interval is punctuated a $\sim 150$-year long variable phase in the LC record (CC3), which does not correlate with any distinct recognized palaeoclimate event in the $\mathrm{NH}$, but was contemporaneous with a 

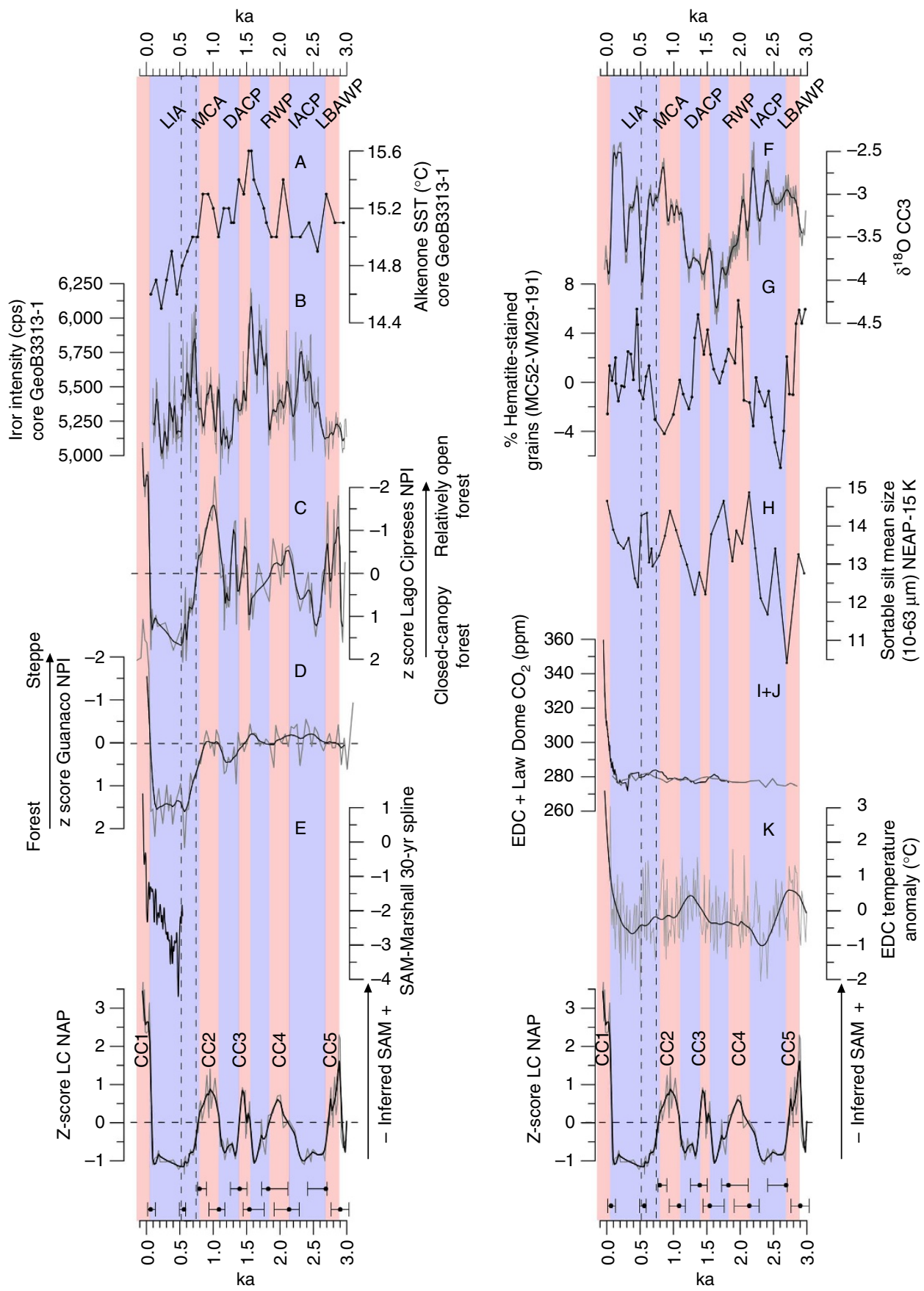

Figure 3 | Intersite comparisons. We compare the standardized Lago Cipreses Non Arboreal Pollen curve (LC NAP; bottom curves) with the alkenone ${ }^{24}$ (A) and Fe intensity data ${ }^{25}$ (B) from core GeoB3313-1, the standardized Nothofagus/Poaceae Indeces (NPI) from LC (C) and Lago Guanaco ${ }^{19}$ (D), a treering-based reconstruction of $\mathrm{SAM}^{14}(\mathrm{E})$, a $\delta^{18} \mathrm{O}$ speleothem record from Northwestern Ireland ${ }^{28}(\mathrm{~F})$, the hematite-stained grain record from North Atlantic cores MC52-VM29-191 (ref. 26; G), the sortable silt record from North Atlantic core NEAP-15K ${ }^{27}(\mathrm{H})$, atmospheric $\mathrm{CO}_{2}$ records ${ }^{32,33}$ from EDC (I) and Law Dome $(J)$ ice cores, and the temperature anomaly record from $\operatorname{EDC}^{31}(\mathrm{~K})$. Also shown are the recognized palaeoclimate anomalies from Europe: Little Ice Age (LIA), Medieval Climate Anomaly (MCA), Dark Ages Cold Period (DACP), Iron Age Cold Period (IACP), Late Bronze Age Warm Period (LBAWP). The oblique and partly overlapping acronymns represent uncertainties and/or geographic heterogeneities for their exact onset and duration. The red and blue vertical rectangles represent the warm/dry and cold/wet phases identified in the Lago Cipreses record, respectively. The dashed vertical rectangle indicates the timing of the highest abundance of Nothofagus during the most recent hyperhumid anomaly.

strongly variable warm pulse in the speleothem record shown in Fig. 3 and, within radiocarbon dating errors, a trough in the icerafted detritus data and a prominent peak in the sortable silt record (Supplementary Discussion). Our results suggest that centennial-scale changes in SAM shared a common structure and timing, within dating uncertainties, with palaeoclimate records from the NH over the last 3000 years. The mechanism(s) governing this interhemispheric symmetry are currently unknown; if replicated by additional high-resolution precisely dated records, this correspondence would imply that palaeoclimate in the northern and southern mid-latitudes were linked through a mechanism residing in the atmosphere, possibly 
through poleward expansions of Hadley cell circulation ${ }^{29}$, solar variability ${ }^{26}$ or, alternatively, through a closely tuned interhemispheric SWW-SO-AMOC-coupled system ${ }^{30}$.

Centennial-scale warm phases in the EPICA Dome C (EDC) ice core from Antarctica ${ }^{31}$ lag behind CC3 and CC5 but coincided in timing during $\mathrm{CC} 1$ (Fig. 3), aspect that might reflect nonstationarities in the temperature change correlation between eastern Antarctica and SAM. The atmospheric $\mathrm{CO}_{2}$ record from Antarctic ice cores ${ }^{32,33}$ shows erratic, low-magnitude variations before the Industrial Revolution that bear no clear relationship with the LC record and EDC temperatures, suggesting that preindustrial changes in the position/strength of the SWW and temperature change in eastern Antarctica since $3 \mathrm{ka}$ were not associated with any salient shifts in the atmospheric $\mathrm{CO}_{2}$ content at centennial timescales. Quite a different situation occurs during the Industrial Revolution (CC1), a time when a prominent $\mathrm{CO}_{2}$ rise correlates with a sustained rise in Antarctic and global temperatures and a positive trend in instrumental, tree-ring and our estimate of palaeo SAM activity.

The LC record suggests that the current trend towards positive SAM resembles pre-industrial oscillations that have taken place repeated times over the last three millennia in the southern midlatitudes. The amplitude of the modern excursion, however, is unprecedented, suggesting that direct (vegetation disturbance) or indirect (atmospheric circulation changes) human perturbations have influenced vegetation change in the LC record since the late nineteeth century. Because recent studies have proposed that the contemporary trend towards positive SAM is largely driven by stratospheric ozone depletion and, secondarily, to increased greenhouse gases $^{7}$, we propose that a juxtaposition of anthropogenic and natural forcing of the $\mathrm{SH}$ climate since the nineteeth century has forced an austral summer poleward shift and year-round intensification of the SWW into sensitive sectors of the $\mathrm{SO}$ where intense degassing of $\mathrm{CO}_{2}$-enriched deep waters currently takes place. This scenario raises the disturbing possibility that intensified SWW-driven upwelling in the SO could lock enhanced release of greenhouse gases from the deep ocean, providing an additional source of positive radiative forcing of future global climate in an already warming world.

\section{Methods}

Stratigraphy. LC $\left(51.285025^{\circ} \mathrm{S}, 72.853494^{\circ} \mathrm{W}, 110\right.$ m.a.s.l. $)$ is a small closed-basin lake located on an ice-scoured bedrock depression over a mountainous terrain near the southwestern sector of Lago Toro (120 m.a.s.l.). Here we obtained three overlapping sediment cores from an anchored raft equipped with a $10-\mathrm{cm}$ wide aluminum casing, using a $5-\mathrm{cm}$ diameter Wright piston corer and a sedimentwater interface piston corer with a $7.5-\mathrm{cm}$ diameter Plexiglas chamber. The cores were taken from the deepest sector of the lake following a bathymetric survey with a sonar. We retrieved overlapping Wright cores PS0710A (287 cm long) and PS0710B (197 cm long), along with the sediment-water interface core PS07SC1 ( $83 \mathrm{~cm}$ long). Correlation between cores was facilitated by results of the loss-onignition analysis and the presence of a $3-\mathrm{cm}$ thick tephra at depth $77-80 \mathrm{~cm}$ in cores PS0710A and PS07SC1 (Supplementary Fig. 4).

The stratigraphy of the cores was characterized by lithological descriptions, digital X-radiographs and loss-on-ignition analysis following overnight drying at $105^{\circ} \mathrm{C}$. We performed sequential burns at 550 and $925^{\circ} \mathrm{C}$ for 2 and $4 \mathrm{~h}$, respectively, to quantify the organic, carbonate and siliciclastic content of the sediments $^{34,35}$. Identification and correlation of tephras with known eruptions of specific source volcanoes in the region were based on petrology and trace-element chemistry determined by inductively coupled plasma mass spectrometry (ICP-MS) analysis. The record shown in this paper includes the upper $121 \mathrm{~cm}$ of the spliced stratigraphy, which consists of silty organic lake mud devoid of carbonates, with a mean organic content of 30\% (Supplementary Fig. 4). Geochemical analysis indicates that the tephra was derived from Volcán Reclús (C. Stern, personnel communication).

Chronology. The chronology of the sediment cores is controlled by ${ }^{210} \mathrm{~Pb}$ and AMS radiocarbon dates (Supplementary Figs 4 and 5) obtained from bulk $1-\mathrm{cm}$ thick sections along the cores. All radiocarbon dates were converted to cal yr BP using the IntCal09 calibration curve included in the CALIB 6.0 software $^{36}$. Based on the radiocarbon data we developed a Bayesian age model (Supplementary Fig. 6) to assign interpolated calendar ages to the levels analysed (Supplementary Fig. 7) using the Bacon package ${ }^{37}$ for R. We used the median probability age calculated for each level and specified the $95 \%$ confidence intervals for each major transition in the LC record. Supplementary Table 3 summarizes the median age probability and associated confidence intervals for the onset and termination of each $\mathrm{CC}$ in cal yr $\mathrm{BP}$ and $\mathrm{AD} / \mathrm{BC}$ timescales. The ${ }^{210} \mathrm{~Pb}$ concentrations were interpreted using the constant rate of supply model of ${ }^{210} \mathrm{~Pb}$ accumulation (Supplementary Table 1 and Supplementary Fig. 5). In addition, we obtained three AMS radiocarbon dates from core PS0710SC1 and four additional from core PS0710A (Supplementary Table 2). The age model takes into account the ${ }^{210} \mathrm{~Pb}$ and AMS radiocarbon dates and the instantaneous deposition of the $\sim 1900 \mathrm{cal}$ yr BP-old tephra. The age model has a median deposition time of 20 years $\mathrm{cm}^{-1}\left(25.8 \pm 20.3\right.$ year $\mathrm{cm}^{-1}($ mean $\pm 1 \sigma)$, minimum: 2.1 year $\mathrm{cm}^{-1}$ at $18 \mathrm{~cm}$, maximum: 98.8 year $\mathrm{cm}^{-1}$ at $14 \mathrm{~cm}$ ). The chronology of the Reclús tephra at depth $77-80 \mathrm{~cm}$ is constrained by the date of sample CAMS-149318 $\left(1.765 \pm 30{ }^{14} \mathrm{C}\right.$ yr BP, median probability: $\left.1,620 \mathrm{cal} \mathrm{yr} \mathrm{BP}\right)$ and constitutes a close minimum limiting age for this event. This date shows good agreement with radiocarbon dates obtained from Pantano Margarita and $\mathrm{LG}^{19}$, sites having depositional settings similar to LC, which yielded a close maximum limiting weighted mean age of 2,000 $\pm 17{ }^{14} \mathrm{C}$ yr BP (1,950 cal yr BP).

Palynology and charcoal analysis. We processed $2 \mathrm{cc}$ sediment samples for pollen analysis using standard techniques that include $\mathrm{KOH}$ deffloculation, concentrated HF treatment and acetolysis ${ }^{38}$. We added Lycopodium spore tablets to the sediment samples to allow calculation of pollen and charcoal concentration and accumulation rates. The concentrates were mounted on glass slides in a silicon oil $(2,000 \mathrm{cs})$ medium and analysed at $\times 400$ and $\times 1,000$ magnification using an Olympus CX31 stereomicroscope. The record shown in this paper consists of 118 palynological levels spanning the last 3,000 years with a median time resolution of 20 years between levels (Supplementary Fig. 7). We counted the pollen and spore content of these samples considering a mean of 586 grains of terrestrial origin per level (minimum: 118, maximum: 1,300), and calculated their percent abundance as a function of this pollen sum. In the case of aquatic plants and ferns, we calculated percentages in reference to sums that included all pollen grains (terrestrial and aquatic) and spores, respectively. Variations in the abundance of these main components are independent considering that their percent abundances were calculated from different, independent sums. The palynological results are shown as percentage data in Supplementary Figs 7-9 and depict variations in the most abundant and informative pollen taxa. Taxa are arranged in terms of terrestrial (arboreal + non arboreal) and aquatic pollen, along with fern spores.

We analysed the macroscopic charcoal content of 2-cc sediment samples taken at contiguous 1-cm thick intervals using the methodology described by Whitlock and Anderson $^{39}$, which includes deflocculating with $10 \% \mathrm{KOH}$ and sieving through 106- and $212-\mu \mathrm{m}$ mesh screens. We counted charcoal particles in each size class under a Zeiss KL1500 LCD stereomicroscope at $\times 50-100$ magnification. The abundance of macroscopic charcoal particles is expressed as charcoal accumulation rate in linear or logarithmic scale (Supplementary Fig. 10).

\section{References}

1. Osborn, T. J. \& Briffa, K. R. The spatial extent of 20th-century warmth in the context of the past 1200 years. Science 311, 841-844 (2006).

2. Moy, C. M., Seltzer, G. O., Rodbell, D. T. \& Anderson, D. M. Variability of El Niño/Southern Oscillation activity at millennial timescales during the Holocene epoch. Nature 420, 162-165 (2002).

3. Yan, H. et al. A record of the Southern Oscillation Index for the past 2,000 years from precipitation proxies. Nat. Geosci. 4, 611-614 (2011).

4. Garreaud, R., Lopez, P., Minvielle, M. \& Rojas, M. Large-Scale Control on the Patagonian Climate. J. Clim. 26, 215-230 (2013).

5. Swart, N. C. \& Fyfe, J. C. Observed and simulated changes in the Southern Hemisphere surface westerly wind-stress. Geophys. Res. Lett. 39, 1-6 (2012).

6. Marshall, G. J. Trends in the southern annular mode from observations and reanalyses. J. Clim. 16, 4134-4143 (2003).

7. Thompson, D. W. J. et al. Signatures of the Antarctic ozone hole in Southern Hemisphere surface climate change. Nat. Geosci. 4, 741-749 (2011).

8. Russell, J. L., Dixon, K. W., Gnanadesikan, A., Stouffer, R. J. \& Toggweiler, J. R. The Southern Hemisphere westerlies in a warming world: propping open the door to the deep ocean. J. Clim. 19, 6382-6390 (2006).

9. Toggweiler, J. R., Russell, J. L. \& Carson, S. R. Midlatitude westerlies, atmospheric $\mathrm{CO} 2$, and climate change during the ice ages. Paleoceanography 21, 1-15 (2006).

10. Denton, G. H. et al. The last glacial termination. Science 328, 1652-1656 (2010).

11. Fletcher, M. S. \& Moreno, P. I. Zonally symmetric changes in the strength and position of the Southern Westerlies drove atmospheric CO2 variations over the past 14 k.y. Geology 39, 419-422 (2011).

12. Garreaud, R. D. Precipitation and circulation covariability in the extratropics. J. Clim. 20, 4789-4797 (2007).

13. Silvestri, G. \& Vera, C. Nonstationary impacts of the southern annular mode on Southern Hemisphere climate. J. Clim. 22, 6142-6148 (2009). 
14. Villalba, R. et al. Unusual Southern Hemisphere tree growth patterns induced by changes in the Southern Annular Mode. Nat. Geosci. 5, 793-798 (2012).

15. Holz, A. \& Veblen, T. T. Wildfire activity in rainforests in western Patagonia linked to the Southern Annular Mode. Int. J. Wildland Fire 21, 114-126 (2012).

16. Moreno, P. I., Villa-Martinez, R., Cardenas, M. L. \& Sagredo, E. A. Deglacial changes of the southern margin of the southern westerly winds revealed by terrestrial records from SW Patagonia (52 degrees S). Quat. Sci. Rev. 41, 1-21 (2012).

17. Moy, C. M. et al. Isotopic evidence for hydrologic change related to the westerlies in SW Patagonia, Chile, during the last millennium. Quat. Sci. Rev. 27, 1335-1349 (2008).

18. Martinic, M. Reconocimiento geográfico y colonización de Última Esperanza, 1870-1910. Anales del Instituto de la Patagonia 5, 5-55 (1974).

19. Moreno, P. I., Francois, J. P., Villa-Martínez, R. \& Moy, C. M. Millennial-scale variability in Southern Hemisphere westerly wind activity over the last 5000 years in SW Patagonia. Quat. Sci. Rev. 28, 25-38 (2009).

20. Masiokas, M. H. et al. 20th-century glacier recession and regional hydroclimatic changes in northwestern Patagonia. Glob. Planet. Change 60, 85-100 (2008).

21. Schaefer, J. M. et al. High-Frequency Holocene Glacier fluctuations in New Zealand differ from the northern signature. Science 324, 622-625 (2009).

22. Villalba, R. et al. Large-scale temperature changes across the southern Andes: 20th-century variations in the context of the past 400 years. Clim. Change. 59, 177-232 (2003)

23. Kilian, R. \& Lamy, F. A review of Glacial and Holocene paleoclimate records from southernmost Patagonia $\left(49-55^{\circ}\right.$ S). Quat. Sci. Rev. 53, 1-23 (2012).

24. Leduc, G., Schneider, R., Kim, J. H. \& Lohmann, G. Holocene and Eemian sea surface temperature trends as revealed by alkenone and $\mathrm{Mg} / \mathrm{Ca}$ paleothermometry. Quat. Sci. Rev. 29, 989-1004 (2010).

25. Lamy, F., Hebbelm, D., Rohl, U. \& Wefer, G. Holocene rainfall variability in southern Chile: a marine record of latitudinal shifts of the southern westerlies. Earth. Planet. Sci. Lett. 185, 369-382 (2001).

26. Bond, G. et al. Persistent solar influence on North Atlantic climate during the Holocene. Science 294, 2130-2136 (2001).

27. Bianchi, G. G. \& McCave, N. Holocene periodicity in North Atlantic climate and deep-ocean flow south of Iceland. Nature 397, 515-517 (1999).

28. McDermott, F. Centennial-scale Holocene climate variability revealed by a high-resolution speleothem delta O-18 record from SW Ireland (9 Nov, pg 1328, 2001). Science 309, 1816-1816 (2005).

29. Previdi, M. \& Liepert, B. G. Annular modes and Hadley cell expansion under global warming. Geophys. Res. Lett. 34, 1-5 (2007).

30. Marini, C., Frankignoul, C. \& Mignot, J. Links between the Southern Annular Mode and the Atlantic Meridional Overturning Circulation in a Climate Model. J. Clim. 24, 624-640 (2011).

31. Jouzel, J. et al. Orbital and millennial Antarctic climate variability over the past 800,000 years. Science 317, 793-796 (2007).
32. MacFarling, M. C. et al. Law Dome $\mathrm{CO}(2), \mathrm{CH}(4)$ and $\mathrm{N}(2) \mathrm{O}$ ice core records extended to 2000 years BP. Geophys. Res. Lett. 33, 1-4 (2006).

33. Monnin, E. et al. Evidence for substantial accumulation rate variability in Antarctica during the Holocene, through synchronization of $\mathrm{CO} 2$ in the Taylor Dome, Dome C and DML ice cores. Earth. Planet. Sci. Lett. 224, 45-54 (2004).

34. Bengtsson, L. \& Enell, M. in Handbook of Palaeoecology and Palaeohydrology. (ed Berglund, B. E.) 423-451 (John Wiley \& Sons, 1986).

35. Heiri, O., Lotter, A. F. \& Lemcke, G. Loss on ignition as a method for estimating organic and carbonate content in sediments: reproducibility and comparability of results. J. Paleolimnol. 25, 101-110 (2001).

36. Reimer, P. J. et al. Intcal09 and Marine09 radiocarbon age calibration curves, 0-50,000 years cal BP. Radiocarbon 51, 1111-1150 (2009).

37. Blaauw, M. \& Christen, J. A. Flexible Paleoclimate Age-Depth Models Using an Autoregressive Gamma Process. Bayesian Anal. 6, 457-474 (2011).

38. Faegri, K. \& Iversen, J. Textbook of Pollen Analysis (John Wiley \& Sons, 1989)

39. Whitlock, C. \& Anderson, R. S. in Fire and Climatic Change in Temperate Ecosystems of the western Americas. (eds Veblen, T. T., Baker, W. L., Montenegro, G. \& Swetnam, T. W.) 265-295 (Springer, 2003).

\section{Acknowledgements}

This study was funded by ICM grants P02-005 and NC120066, Fondap 15110009, CONICYT USA2013-0035, Fondecyt 1131055. We are grateful to L Hernández for sampling, processing and laboratory analyses at U. de Chile, RA Flores, MR Kaplan, CM Moy and EA Sagredo for assistance during field work, and the Chilean Army for logistical support. We thank T Guilderson, CM Moy and CR Stern for conducting radiocarbon and tephra analyses during the initial phase of this study.

\section{Author contributions}

P.I.M. and R.V.-M. obtained the initial funding for this study, selected the study site, carried out the coring operation and conducted the initial analyses. I.V. developed the high-resolution palynology, R.D.G. and M.R. contributed with the modern climate analyses and R.DeP.-H. collaborated with the radiocarbon chronology. P.I.M. wrote the paper with the contribution of all authors.

\section{Additional information}

Supplementary Information accompanies this paper at http://www.nature.com/ naturecommunications

Competing financial interests: The authors declare no competing financial interests.

Reprints and permission information is available online at http://npg.nature.com/ reprintsandpermissions/

How to cite this article: Moreno, P. I. et al. Southern Annular Mode-like changes in southwestern Patagonia at centennial timescales over the last three millennia. Nat. Commun. 5:4375 doi: 10.1038/ncomms5375 (2014). 